\title{
Leishmania infantum in the reproductive organs of dogs
}

\author{
Diogo Tiago da Silva ${ }^{1,2}$ iD Maria Luana Alves ${ }^{1,3}$ (D) Julio Cesar Pereira Spada ${ }^{1,2}$ \\ João Augusto Franco Leonel ${ }^{1,3}$ (D) Julia Cristina Benassi ${ }^{3}$ iD Wilma Aparecida Starke-Buzetti ${ }^{4}$ \\ Helena Lage Ferreira ${ }^{1,3}$ Lara Borges Keid ${ }^{1,3}$ Rodrigo Martins Soares, \\ Trícia Maria Ferreira de Sousa Oliveira ${ }^{1,3^{*}}$ iD
}

\begin{abstract}
${ }^{1}$ Programa de Pós-graduação em Epidemiologia Experimental Aplicada às Zoonoses, Departamento de Medicina Veterinária Preventiva e Saúde Animal, Faculdade de Medicina Veterinária e Zootecnia, Universidade de São Paulo (USP), Pirassununga, SP, Brasil. E-mail: tricia@usp.br. ${ }^{*}$ Corresponding author.

${ }^{2}$ Faculdade de Ciências Agrárias de Andradina, Fundação Educacional de Andradina, Andradina, SP, Brasil.

${ }^{3}$ Laboratório de Medicina Veterinária Preventiva Aplicada, Departamento de Medicina Veterinária, Faculdade de Zootecnia e Engenharia de Alimentos, Universidade de São Paulo (USP), Pirassununga, SP, Brasil.

${ }^{4}$ Departamento de Biologia e Zootecnia, Faculdade de Engenharia de Ilha Solteira, Universidade do Estado de São Paulo (UNESP), Ilha Solteira, SP, Brasil.

${ }^{5}$ Departamento de Medicina Veterinária Preventiva e Saúde Animal, Faculdade de Medicina Veterinária e Zootecnia, Universidade de São Paulo (USP), Pirassununga, SP, Brasil.
\end{abstract}

ABSTRACT: Leishmania infantum causes canine leishmaniasis. Using parasitological and molecular analyses, we identified L. infantum in the reproductive organs of male and female dogs. Using histochemistry, immunohistochemistry, and PCR, we examined tissue samples from the reproductive organs of 8 male dogs and 16 female dogs diagnosed with leishmaniasis. Despite the absence of macroscopic or microscopic lesions in these organs, we observed L. infantum amastigotes in tissue samples from the testis and the uterus. PCR and sequencing of these tissues revealed sequences that matched 100\% with L. infantum DNA available at GenBank. The presence of L. infantum amastigotes and DNA in testicular and uterine tissue samples suggested that these organs can harbor the parasite without associated macroscopic or microscopic lesions, and this can be especially important in the vertical and venereal transmission of leishmaniasis in dogs.

Key words: histochemical, immunohistochemical, leishmaniasis, testis, uterus.

\section{Leishmania infantum em órgãos reprodutivos de cães}

RESUMO: Leishmania infantum é agente etiológico da leishmaniose canina. Por meio de análises parasitológicas e moleculares, a presença do parasita foi investigada em órgãos reprodutivos de cães machos e fêmeas. Amostras de tecidos dos órgãos reprodutivos de 8 cães machos e 16 fêmeas diagnosticados com leishmaniose foram avaliadas por histoquímica, imunohistoquímica e PCR. Apesar de não terem sido observadas lesões macroscópicas ou microscópicas nos órgãos reprodutivos desses cães, formas amastigotas de L. infantum foram observadas em amostras teciduais do testículo e útero. A PCR e o sequenciamento do DNA extraído desses tecidos revelaram sequências $100 \%$ idênticas a L. infantum depositadas no GenBank. Nossos resultados sugerem que os testículos e o útero podem abrigar o parasita, sem associação com lesões macroscópicas ou microscópicas, o que pode ter uma grande importância na transmissão venérea e vertical da leishmaniose entre cães. Palavras-chave: histoquímica, imunohistoquimica, leishmaniose, testículo, útero.

\section{INTRODUCTION}

Leishmania infantum causes human and animal cases of visceral leishmaniases. Dogs are the main epidemiological reservoir of the parasite in the domestic environment, and vectorial transmission by sand flies is the most important means of infection (SOLANO-GALLEGO et al., 2011).
Many infected dogs remain without clinical signs; however, canine leishmaniasis (CanL) is a systemic disease characterized by nonspecific clinical signs (SOLANO-GALLEGO et al., 2011). L. infantum infection or DNA has been reported in several canine tissues, organs, and body fluids (TAFURI et al., 2004; SOLANO-GALLEGO et al., 2011; SILVA et al., 2016; FERNANDES et al., 2019), including those 
present in the genital system (DINIZ et al., 2005; SILVA et al., 2008; AMARA et al., 2009; MANNA et al., 2012; BOECHAT et al., 2016; OLIVEIRA et al., 2016a, 2016b; MAGRO et al., 2017). In particular, infection of the canine reproductive tract has received substantial attention since venereal and vertical transmission were reported (PANGRAZIO etal., 2009; SILVA et al., 2009). Early vertical transmission to the embryo in a pregnant dog infected with $L$. infantum was detected by molecular means (OLIVEIRA et al., 2017). In the United States, where vectorial transmission $L$. infantum has not been proven, cases of vertical transmission in dogs appear to be important for the maintenance of the parasite circulation in the population (BOGGIATTO et al., 2011; TOEPP et al., 2019). This phenomenon highlights alternative routes of $L$. infantum transmission that can be important for the maintenance of parasite communities in canine populations.

In this study, using parasitological and molecular methods, we searched for $L$. infantum amastigote forms and DNA in the reproductive organs of dogs diagnosed with leishmanianis from an endemic area of Brazil.

\section{MATERIALS AND METHODS}

During an epidemiological survey conducted by the Zoonotic Disease Control Center (ZDCC) of Ilha Solteira, São Paulo, Brazil, investigators diagnosed Leishmania spp. infections in 24 dogs of several breeds, both sexes ( 8 males and 16 females) and various ages (mean age: 3.2 years). The detection methods included (a) direct parasitological examination of popliteal or pre-scapular lymph node aspirate stained with Panótico ${ }^{\circledR}$ staining kit (Laborclin); (b) immunochromatographic testing (Dual Parth Platform - DPP ${ }^{\circledR}$, Biomanguinhos); and (c) indirect ELISA testing (Biomanguinhos). All dogs presented with clinical signs suggestive of CanL, including skin lesions, lymphadenopathy, loss of body weight, lethargy, mucous membrane pallor, ocular lesions, diarrhea, splenomegaly, and hepatomegaly (SOLANO-GALLEGO et al., 2011). The dogs' owner transported the dogs to the ZDCC for euthanasia in accordance with the dictates of the Brazilian visceral leishmaniases control program. We collected tissue samples from reproductive organs of all 24 dogs as donations from the ZDCC. The study was approved by the Ethics Committee for Animal Use (CEUA) of Faculdade de Engenharia de Ilha Solteira, Universidade do Estado de São Paulo (FEIS/UNESP) under protocol number 06/2014-
CEUA.

We collected fragments of tissue approximately $1 \mathrm{~cm}$ in size from the reproductive organs (ovaries and uteruses from females and testes from males). We fixed some of the tissue in $10 \%$ formalin with $0.01 \mathrm{M}$ phosphate-buffered saline for histochemical (HC) and immunohistochemical (IHC) analyses. We stored the remaining tissue in $1.5-\mathrm{mL}$ sterile microtubes at $-20{ }^{\circ} \mathrm{C}$ for molecular analyses.

About $\mathrm{HC}$, the tissues were fixed and then embedded in paraffin. We created histological sections of $5 \mu \mathrm{m}$ thickness and stained them with hematoxylin and eosin for histopathological examination. Then, we evaluated three sections of each tissue under an optical microscope at $40 \times$ or $100 \times$ magnification.

For IHC, we performed immunostaining of $L$. infantum amastigotes according to procedures described by TAFURI et al. (2004) with modifications by QUEIROZ et al. (2011). We hydrated the deparaffinized slides and incubated them in hydrogen peroxide (Fluka Chemie AG, CH-9470 Buchs, Switzerland) to block endogenous peroxidase activity. Next, we incubated the slides in normal goat serum (1:50 dilution) to block nonspecific immunoglobulin absorption in the tissue. The primary antibody was immune serum from dog that was naturally infected with $L$. infantum (ELISA and IFAT titers $=1: 2.560$ ). The secondary antibody was a biotinylated rabbit anti-IgG antibody produced in goat (BA-1000, Vector Laboratories, Inc., Burlingame, CA, USA). After appropriate washes, we incubated tissue sections in a solution of avidin-biotin-peroxidase complex (Vectastain ABC Kit PK 6200; Vector Laboratories Inc., Burlingame, CA, USA), followed by incubation with the peroxidase substrate (Nova REDTM substrate Kit SK-4800; Vector Laboratories Inc., Burlingame, CA, USA). Finally, we counterstained the sections with Mayer's hematoxylin and mounted them on glass slides. The tissue samples were positive when extra or intramacrophagic amastigote forms were specifically immunostained with red/brown color in at least one tissue section under an optical microscope (at $40 \times$ or $100 \times$ ).

We performed DNA extraction from the tissue samples using the Illustra ${ }^{\mathrm{TM}}$ Blood Genomic Prep Mini Spin kit (GE Healthcare) in accordance with the manufacturer's recommendations.

The PCR reactions of each sample proceeded using the internal transcribed spacer 1 (ITS-1) region of the rDNA of the Trypanosomatidae family using the primers LITSR (5'-CTGGATCATTTTCCGATG-3') and L5.8S (5'-TGATACCACTTATCGCACTT-3') that

Ciência Rural, v.51, n.10, 2021. 
annealed to the conserved sequences SSU and 5.8S. as described by EL TAI et al. (2000). We used an L. infantum (syn. Leishmania chagasi, MCAN/ BR/1984/CCC-17.481) DNA sample provided by the Fundação Oswaldo Cruz (FIOCRUZ), Rio de Janeiro, Brazil, as a positive control. Sterilized ultrapure water was the negative control. We performed PCR gel electrophoresis on 1.5\% agarose gels and subjected PCR products to DNA sequencing as described by FERNANDES et al. (2019).

\section{RESULTS}

All 24 infected dogs presented some clinically suggestive signs of CanL. We recorded onychogryphosis $(75 \% ; 18 / 24)$, skin lesions $(70.8 \%$; $17 / 24)$, weight loss $(62.5 \%$; 15/24), lymph node enlargement $(50 \% ; 12 / 24)$, alopecia $(45.8 \% ; 11 / 24)$, splenomegaly $(45.8 \% ; 11 / 24)$, hepatomegaly $(25 \%$; $6 / 24)$, corneal opacity $(25 \% ; 6 / 24)$ and diarrhea $(12.5 \%$; 3/24). Dogs were euthanized at the ZDCC and tissue samples from the reproductive organs were collected and subjected to parasitological (HC and IHC) and molecular (PCR) methods to identify parasites.

First, it is important to highlight that we observed neither macroscopic nor microscopic lesions on the genital organs we sampled in this study. $\mathrm{HC}$ and IHC showed L. infantum amastigote forms present in the connective tissue of the seminiferous tubules from the testes of two dogs $(25 \% ; 2 / 8)$ (Table 1; Figure 1C-D). We observed amastigotes in the endometrium of the uterus in two females using IHC $(12.5 \%$; 2/16) (Table 1; Figure 1A-B). There were no $L$. infantum amastigote forms in ovarian tissue samples, according to $\mathrm{HC}$ and IHC (Table 1).

Tissue samples from 10 dogs $(41.7 \%$; $10 / 24)$, four testis tissue samples $(50 \% ; 4 / 8)$, and six uterus tissue samples $(37.5 \% ; 6 / 16)$ were PCR positive for the ITS-1 region (Table 1). As in HC and IHC, none of the ovarian tissue samples were ITS-1 PCR-positive (Table 1). Upon sequencing, all sequences showed $100 \%$ identity with $L$. infantum (similarity with sequence deposited on GenBank under accession number KM677131.1).

\section{DISCUSSION}

Ten dogs diagnosed with leishmaniasis were positive for DNA or amastigotes of $L$. infantum in their reproductive organs (testis and uterus), without macroscopic or microscopic alterations.

The presence of Leishmania spp. in the male genital system was reported by other authors in external (glans, urethral, prepuce, scrotum) and internal genitalia (testis, epididymis, prostate) of infected dogs without clinical signs or overt illness (DINIZ et al., 2005; AMARA et al., 2009; MANNA et al., 2012; BOECHAT et al., 2016; OLIVEIRA et al., 2016a). In the present study, we identified $L$. infantum amastigotes and DNA in tissue samples of testis from infected and sick male dogs (Figure 1CD), without macroscopic or microscopic alterations observed in the testes. Orchitis was associated with amastigote forms in canine testicular tissues, where they probably acted as factors triggering chronic inflammatory responses (DINIZ et al., 2005; MANNA et al., 2012). BOECHAT et al. (2016) observed testicular degeneration, atrophy, absence of spermatogenesis, and necrosis related to the presence of the infection. It is clear that testis involvement could result in shedding of the amastigotes in the semen, favoring venereal transmission of the disease (MANNA et al., 2012; OLIVEIRA et al., 2016a).

In the female genital system, external (vulva, vagina, and mammary glands) and internal

Table 1 - L. infantum amastigotes and DNA detection by histochemical (HC), immunohistochemical (IHC), and PCR methods in the genital organs of sick male and female dogs, diagnosed with leishmaniasis.

\begin{tabular}{lccccccc}
\hline Dogs & Number & Clinical signs & Organs & HC & IHC & PCR & Sequencing \\
\hline Male & 8 & $100 \%(8 / 8)$ & Testis & $25 \%(2 / 8)$ & $25 \%(2 / 8)$ & $50 \%(4 / 8)$ & $100 \%$ L. infantum \\
Female & 16 & $100 \%(16 / 16)$ & Uterus & 0 & $\begin{array}{c}12.5 \% \\
(2 / 16)\end{array}$ & $\begin{array}{l}37.5 \% \\
(6 / 16)\end{array}$ & $100 \%$ L. infantum \\
& & & Ovaries & 0 & 0 & - \\
\hline
\end{tabular}




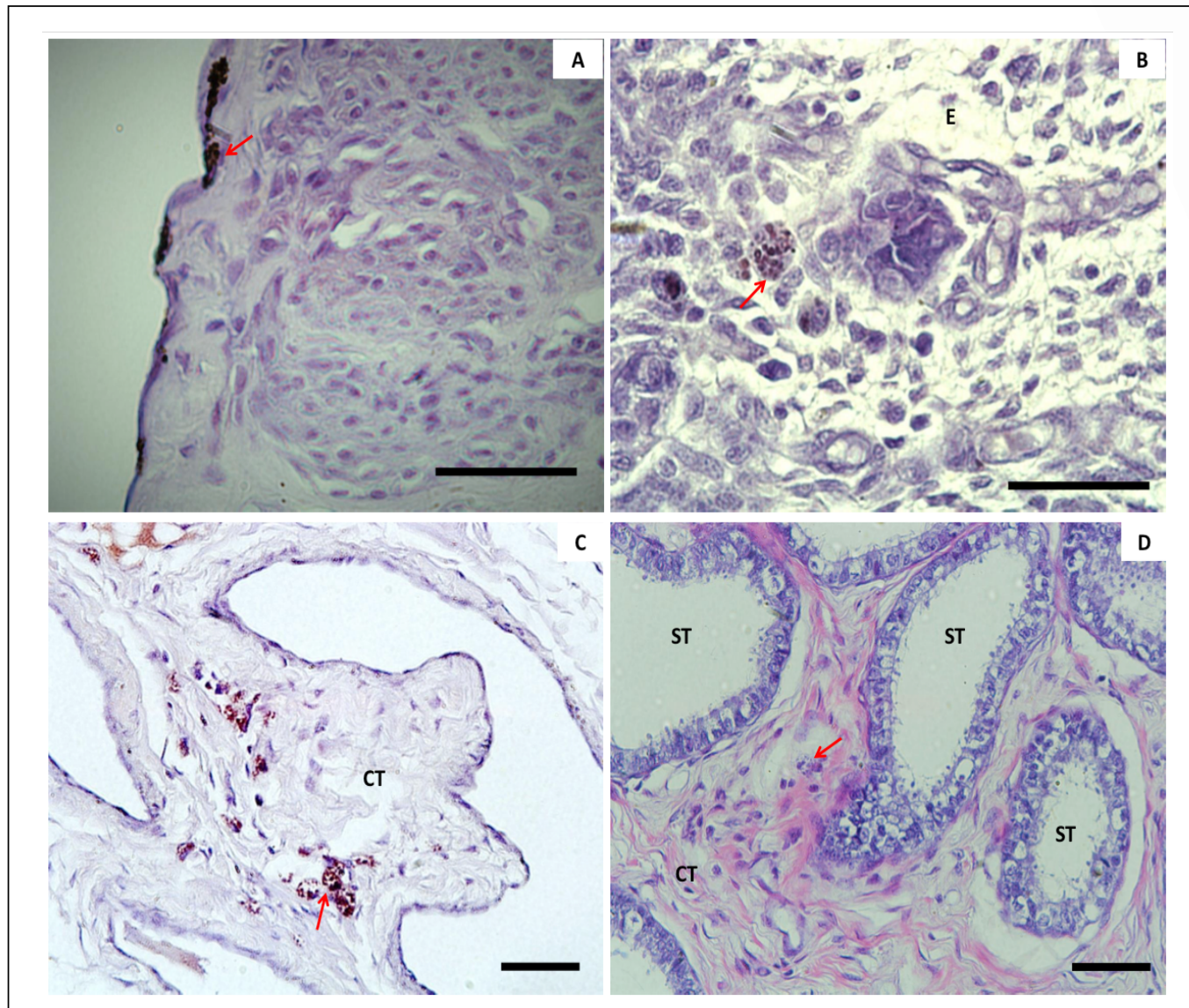

Figure 1 - Histological sections of testicular and uterine tissues from sick male and female dogs, diagnosed with canine leishmaniasis (CanL), staining for histochemical (HC) and immunohistochemical (IHC) analyses. L. infantum amastigotes (red arrows) in the endometrium (E) of uterus by IHC, under magnification 100× (A and B); L. infantum amastigotes (red arrows) in the connective tissue (CT) of seminiferous tubules (ST) of testicle by IHC (C) and by HC (D) both under magnification $40 \times$. Bars $=50 \mu \mathrm{m}$.

genitalia (ovary, uterus, cervix) were reported to harbor Leishmania spp. in infected female dogs without clinical signs or overt illness (SILVA et al., 2008; BOECHAT et al., 2016; OLIVEIRA et al., 2016b; BOECHAT et al., 2020; MAGRO et al., 2017). In our study, we identified L. infantum amastigotes and DNA in uterine tissue samples from infected and sick female dogs (Figure 1A-B). Unlike the present study, Leishmania amastigotes forms and DNA were reported in ovaries in other studies (SILVA et al., 2008; BOECHAT et al., 2016; OLIVEIRA et al., 2016a).

In the present study, we reported a higher proportion of $L$. infantum infection in the reproductive organs of male dogs $(50 \%)$ than in females $(37.5 \%)$. Other studies suggested a tropism for the canine male genital system, particularly the epididymis, prepuce, and glans penis, resulting in inflammation of these organs, with shedding of the organism into the semen. This contributed to venereal transmission of the parasite during copulation from male to female dogs (SILVA et al. 2008). In fact, the venereal transmission of $L$. infantum in dogs was demonstrated only from male to female (SILVA et al., 2009). However, BOECHAT et al. (2020) demonstrated similar $L$. infantum active infections in female and male dogs, with vagina, testis, vulva, and epididymis showing the highest frequencies of active infection.

In females, the presence of the infection in the uterus, without lesions, reinforces the notion that vertical transmission of canine leishmaniasis should receive more attention. These routes of infection

Ciência Rural, v.51, n.10, 2021. 
appear to be responsible for the maintenance of the parasite in areas of the United States where vectorial transmission is unproven, with a high risk of transmission from mother to offspring (BOGGIATTO et al., 2011; TOEPP et al., 2019).

Our study highlights the visceralization pattern of $L$. infantum infection reaching the canine reproductive organs from naturally-infected male and female dogs. The presence of $L$. infantum amastigotes and DNA in testicular and uterine tissue samples from dogs with CanL suggests that these organs can harbor the parasite without associated macroscopic or microscopic lesions.

\section{CONCLUSION}

We found evidence for $L$. infantum infection in the testis and uterus of dogs. Our findings reinforce the notion of venereal and vertical transmission as a means of transmission of CanL in endemic areas.

\section{ACKNOWLEDGMENTS}

The authors thank the Zoonotic Disease Control Center from the city of Ilha Solteira, São Paulo, Brazil, for the donation of the biological material from the reproductive organs of the dogs. The study received financial support provided by Fundação de Amparo à Pesquisa do Estado de São Paulo (FAPESP) under project number 2013/13875-5 and by the Coordenação de Aperfeiçoamento de Pessoal de Nível Superior - Brasil (CAPES) - Finance Code 001.

\section{BIOETHICS AND COMMITTEE APPROVAL BIOSSECURITY}

The study was approved by the Ethics Committee for Animal Use (CEUA) of Faculdade de Engenharia de Ilha Solteira, Universidade do Estado de São Paulo (FEIS/UNESP) under protocol number 06/2014-CEUA.

\section{DECLARATION OF CONFLICT OF INTERESTS}

The authors declare no conflict of interest. The founding sponsors had no role in the design of the study; in the collection, analyses, or interpretation of data; in the writing of the manuscript, and in the decision to publish the results.

\section{AUTHORS' CONTRIBUTIONS}

All authors contributed equally to the design and writing of the manuscript.

\section{REFERENCES}

AMARA, A. et al. Etude histologique des lésions testiculaires chez les chiens leishmaniens. Revue de Médecine Vétérinaire, Toulouse, v.
160, n. 1, p. 54-60, 2009. Available from: < https://www.revmedvet. com/2009/RMV160_54_60.pdf >.Accessed: Aug 5, 2020.

BOECHAT, V. C. et al. Frequency, active infection and load of Leishmania infantum and associated histological alterations in the genital tract of male and female dogs. PLoS ONE, San Francisco, v. 15, n. 9, e0238188, 2020. Available from: <https:// doi.org/10.1371/journal.pone.0238188>. Accessed: Oct 15, 2020. doi: 10.1371/journal.pone.0238188.

BOECHAT, V. C. et al. Occurrence of Leishmania infantum and associated histological alterations in the genital tract and mammary glands of naturally infected dogs. Parasitology Research, Berlin, v. 115 , n. 6, p. 2371-2379, 2016. Available from: $<$ https://doi. org/10.1007/s00436-016-4987-4>. Accessed: Jun 29, 2020. doi: $10.1007 / \mathrm{s} 00436-016-4987-4$

BOGGiATTO, P. M. et al. Transplacental transmission of Leishmania infantum as a means for continued disease incidence in North America. PLOS Neglected Tropical Diseases, San Francisco, v. 5, n. 4, e1019, 2011. Available from: < https://doi. org/10.1371/journal.pntd.0001019>. Accessed: Aug 10, 2020. doi: 10.1371/journal.pntd.0001019.

DINIZ, S. A. et al. Genital lesions associated with visceral leishmaniasis and shedding of Leishmania sp. in the semen of naturally infected dogs. Veterinary Pathology, Thousand Oaks, v. 42, n. 5, p. 650-658, 2005. Available from: $<$ https://doi. org/10.1354/vp.42-5-650>. Accessed: May 20, 2020. doi: 10.1354/ vp.42-5-650.

EL TAI, N. O. et al. Genetic heterogeneity of ribosomal internal transcribed spacer in clinical samples of Leishmania donovani spotted on filter paper as revealed by single-strand conformation polymorphisms and sequencing. Transactions of the Royal Society of Tropical Medicine and Hygiene, London, v. 94, n. 5, p. $575-579,2000$. Available from: <https://doi.org/10.1016/ S0035-9203(00)90093-2>. Accessed: May 10, 2020. doi: 10.1016/ S0035-9203(00)90093-2.

FERNANDES, M. A. et al. Molecular detection of Leishmania infantum DNA according to clinical stages of leishmaniasis in dog. Brazilian Journal of Veterinary Parasitology, Jaboticabal, v. 28, n. 2, p. 194-202, 2019. Available from: <https://doi.org/10.1590/ s1984-29612019015>. Accessed: May 10, 2020. doi: 10.1590/ s1984-29612019015.

MAGRO, A. G. et al. Leishmania infantum is present in vaginal secretions of naturally infected bitches at lower levels in oestrogenized bitches than in non-oestrogenized bitches. Acta Parasitologica, Warszawa, v. 62, n. 3, p. 625-629, 2017. Available from: <https://doi.org/10.1515/ap-2017-0076>. Accessed: Aug 10, 2020. doi: 10.1515/ap-2017-0076.

MANNA, L. et al. Detection of Leishmania parasites in the testis of a dog affected by orchitis: Case report. Parasites \& Vectors, London, v. 5, p. 216, 2012. Available from: <https:// doi.org/10.1186/1756-3305-5-216>. Accessed: Jul 20, 2020. doi: $10.1186 / 1756-3305-5-216$.

OLIVEIRA, V. V. G. et al. Correlation between chronic inflammation, immunostaining and parasite load in the genital system of female dogs naturally infected with Leishmania infantum. Ciência Rural, Santa Maria, v. 46, n. 11, p. 2029-2035, 2016 b. Available from: < https://doi.org/10.1590/0103-8478cr20160137>. Accessed: May 4, 2020. doi: 10.1590/0103-8478cr20160137. 
OLIVEIRA, V. V. G. et al. Histopathological evaluation and parasite quantification (qPCR) in the male dog's genital system after natural infection with Leishmania infantum. Ciência Rural, Santa Maria, v. 46, n. 4, p. 641-647, 2016a. Available from: <https://doi. org/10.1590/0103-8478cr20150850>. Accessed: Aug 6, 2020. doi: $10.1590 / 0103-8478 \mathrm{cr} 20150850$.

OLIVEIRA, V. V. G. et al. Molecular evidence of early vertical transmission of Leishmania (Leishmania) infantum in a dog. Ciência Rural, Santa Maria, v. 47, n. 1, e20160553, 2017. Available from: $<\mathrm{http} / / / \mathrm{dx}$.doi.org/10.1590/0103-8478cr20160553>. Accessed: Aug 6, 2020. doi: 10.1590/0103-8478cr20160553.

PANGRAZIO, K. K. et al. Tissue distribution of Leishmania chagas and lesions in transplacentally infected fetuses from symptomatic and asymptomatic naturally infected bitches. Veterinary Parasitology, Amsterdam, v. 165, n. 3-4, p. 327-331, 2009. Available from: $<$ https:// doi.org/10.1016/j.vetpar.2009.07.013>. Accessed: Aug 10, 2020. doi: 10.1016/j.vetpar.2009.07.013.

QUEIROZ, N. M. G. P. et al. Detection of Leishmania (L.) chagasi in canine skin. Veterinary Parasitology, Amsterdam, v. 178, n. 1-2, p. 1-8, 2011.Available from: $<$ http://dx.doi.org/10.1016/j. vetpar.2010.12.033>. Accessed: Jul 10, 2020. doi: 10.1016/j. vetpar.2010.12.033.

SILVA, D. T. da et al. Correlation study and histopathological description of intestinal alterations in dogs infected with Leishmania infantum. Brazilian Journal of Veterinary Parasitology, Jaboticabal, v. 25 , n. 1, p. 24-36, 2016. Available from: <https://doi.org/10.1590/ s1984-29612016009>. Accessed: Jul 10, 2020. doi: 10.1590/s198429612016009.
SILVA, F. L. et al. Genital lesions and distribution of amastigotes in bitches naturally infected with Leishmania chagasi. Veterinary Parasitology, Amsterdam, v. 151, n. 1, p. 86-90, 2008. Available from: <https://doi.org/10.1016/j.vetpar.2007.09.032>. Accessed: Jul 10, 2020. doi: 10.1016/j.vetpar.2007.09.032.

SILVA, F. L. et al. Venereal transmission of canine visceral leishmaniasis. Veterinary Parasitology, Amsterdam, v. 160, n. 1-2, p. 55-59, 2009. Available from: <https://doi.org/10.1016/j. vetpar.2008.10.079>. Accessed: Jun 20, 2020. doi: 10.1016/j. vetpar.2008.10.079.

SOLANO-GALLEGO, L. et al. LeishVet guidelines for the practical management of canine leishmaniosis. Parasites \& Vectors, London, v. 4, p. 86, 2011. Available from: <https://doi. org/10.1186/1756-3305-4-86>. Accessed: Jun 20, 2020. doi: $10.1186 / 1756-3305-4-86$.

TAFURI, W. L. et al. An alternative immunohistochemical method for detecting Leishmania amastigotes in paraffin-embedded canine tissues. Journal of Immunological Methods, Amsterdam, v. 292, n. 1-2, p. 17-23, 2004. Available from: <https://doi.org/10.1016/j. jim.2004.05.009>. Accessed: Jun 20, 2020. doi: 10.1016/j. jim.2004.05.009.

TOEPP, A. J. et al. Maternal Leishmania infantum infection status has significant impact on leishmaniasis in offspring. PLOS Neglected Tropical Diseases, San Francisco, v. 13, n. 2, e0007058, 2019. Available from: <https://doi.org/10.1371/journal. pntd.0007058>. Accessed: Oct 10, 2020. doi: 10.1371/journal. pntd.0007058. 